\title{
ACQUISITION OF EXPLORATION AND PRODUCTION RIGHTS OUTSIDE OF CANADA
}

\author{
ROBERT F. NEWBY*
}

From a practical point of view, the author examines problems which may be encountered in determining the most suitable method of acquisition of exploration and production rights outside of Canada. The paper deals with the evaluation of fiscal and operational considerations, including tax ramifications of alternatives in both Canada and the host country. It deals briefly with practical factors in assessment of the investment climate in the host country; and, it deals extensively with selection of the most appropriate corporate vehicle through which to hold the concession, examining the comparative advantages and disadvantages of branches and subsidiaries with special attention to tax implications.

\section{INTRODUCTION}

This paper is intended to provide a general outline of matters which should be considered by a company resident in Canada, when the acquisition of exploration and production rights in a jurisdiction outside of Canada is contemplated. The paper is divided into the following areas of concern:

1. Assessing fiscal and operational aspects of the agreement granting the exploration and production rights (the "concession").

2. Assessing the investment climate of the country in which operations are contemplated (the "host country").

3. Choosing the corporate vehicle which is to hold the concession.

As there is usually little that legal counsel can do about the investment climate of the host country, most of the paper is devoted to the other two subjects, with the greater emphasis on the considerations to be weighed in choosing the corporate vehicle to be used to hold the concession.

\section{ASSESSING THE FISCAL AND OPERATIONAL ASPECTS OF THE CONCESSION}

The matters to be considered in negotiating the terms of a concession, or assessing its attractiveness from a fiscal and operational viewpoint, will be considered under the following headings:

(a) Canadian tax considerations.

(b) Host country tax considerations.

(c) Operational considerations.

\section{A. Canadian Tax Considerations}

In the typical Canadian situation, a taxpayer carrying on exploration activities has, or is entitled to earn, an interest (usually leasehold) which, in effect, amounts to ownership of the minerals, subject only to such royalties as may be reserved. In the past, this format for exploration was also common outside of Canada. However, current

\footnotetext{
- Barrister and Solicitor, Burnet, Duckworth \& Palmer, Calgary, Alberta.
} 
political trends, particularly in developing countries, require that the state retain ownership and control of its petroleum resources, and that exploration companies be seen only to assist the state in exploiting such resources by providing technical services. Sundry forms of service and technical assistance contracts have therefore come into use. (Examples are to be found in Indonesia, the Philippines, Malaysia, India, Bangladesh, Egypt, Libya, Uruguay, Bolivia, and now in the Arabian Gulf, as a result of recent nationalizations.)

As the special provisions of the Income Tax Act of Canada (the "Act"), relating to the petroleum industry, were intended to cover the typical Canadian situation, they may not apply to such forms of agreement. In addition, the value of the share of production taken or retained by the state under such agreements in lieu of taxes may not give rise to a foreign tax credit in Canada. The terms of the concession must accordingly be examined to determine the following:

(i) Is the concession a foreign resource property within the meaning of the Act?

(ii) Will expenses incurred thereunder constitute foreign exploration and development expenses under the Act?

(iii) Will income thereunder be foreign resource income as described in Section 66(4)(b)(ii) of the Act?

(iv) Will amounts paid to the host country be considered taxes with respect to which a foreign tax credit will be available under Section 126 of the Act?

The significance, for Canadian tax purposes, of the above questions is as follows:

(i) If the concession is a foreign resource property, acquisition costs will be deductible as foreign exploration and development expenses, and proceeds received upon disposition of the concession will be taxed as income. If the concession is not a foreign resource property, acquisition costs may be considered a nondeductible capital expense and, similarly, proceeds of disposition may be treated on a capital gains basis.

(ii) If expenses incurred in operations under the concession are foreign exploration and development expenses, they will be deductible according to the rules set forth in Section 66(4) of the Act, which may not be as beneficial to the taxpayer as if they were treated as ordinary expenses incurred in producing income.

(iii) Foreign exploration and development expenses are deductible to the extent that the taxpayer has foreign resource income as described in Section 66(4)(b)(ii) of the Act. It is accordingly important that income from the concession be considered as income within the meaning of that section, if the taxpayer will have foreign exploration and development expenses.

(iv) If income taxes are levied in the host country at a rate not less than the Canadian rate, and if credit therefor is allowed under Section 126 of the Act, income from the concession may be brought to Canada free of Canadian income tax. If credit is not given for all payments to the host government, additional Canadian taxes will be imposed, and the project will be less attractive. 
If there is doubt as to the characterizations referred to in subparagraphs (i) to (iii) above, the possible advantages and disadvantages of treating the operation as an ordinary business, not subject to the special resource industry rules, should be considered. In the absence of offsetting foreign resource income, there may be some merit to characterizing the exploration expenses as ordinary expenses from a business, in order that they be deductible against income from all sources. However, if the company in question does not have sufficient income, the expenses may be lost for tax purposes, by virtue of the five year carry-forward limitation on non-capital losses.

To the extent that the terms of the concession are negotiable, an attempt should be made to alter the terms thereof, to support the desired characterizations of income and expenses.

\section{B. Host Country Tax Considerations}

The combined effect of the terms of the concession and applicable law in the following areas should be considered:

(i) Current rate of taxes on income.

(ii) Other types of taxes applicable to contemplated operations.

(iii) Limitation on types and levels of taxes applicable to the concessionaire.

(iv) Tax treatment of contractors and personnel of the concessionaire.

(v) Treatment of expenditures in calculating income tax (types of expenditures deductible and rates of deduction).

(vi) Rights of consolidation of accounts for tax purposes if other businesses are carried on or other concessions are obtained in the host country.

(vii) Restrictions and withholding taxes on repatriation of income and capital from the host country.

\section{Operational Considerations}

While each term of the concession, and each applicable law, is of potential importance to the concessionaire, the following are some of the areas in which problems are likely to be encountered, and which should be considered with particular care:

(i) Area covered by concession: Ensure that the boundaries of the concession are as intended, and ascertain whether there is, or is likely to be, a jurisdictional dispute with neighbouring countries which is likely to affect the concession.

(ii) Substances: Ensure that the concession and the law define, with sufficient clarity, the substances which may be taken; this is particularly important if natural gas rights are withheld by the host country, or are otherwise subject to exploitation by a third party (such as has occurred in Egypt, Ecuador and the United Arab Emirate of Dubai).

(A) Nature, timing and amount of work obligations, and provisions for reduction in the event of surrender or forfeiture of the concession. (Reductions are particularly important where performance bonds have been posted.)

(B) Standard of care required in conducting operations.

(C) Extent of liability for damage to the environment. 
(D) Extent of other possible liability for damage, or breach of contract.

(E) Technical problems in complying with work obligations, due to climatic conditions.

(iv) Adequacy of operational rights:

(A) Rights to use surface and water as needed.

(B) Adequacy of existing transportation and communication facilities, and rights to upgrade these as needed.

(C) Rights to import and export necessary materials and equipment, without taxes or restrictions.

(D) Cooperation from immigration and related departments of the host country government, to ensure free rights of entry and exit for personnel (ease of obtaining necessary visas and work permits).

(E) Right to delegate work to contractors.

(F) Right to appoint an operating company to carry out the operations.

(G) Rights to extract and take petroleum: Concessions in the nature of service or technical assistance contracts may not specifically include the right to take or remove petroleum from the ground (although the concessionaire will have the right to receive a share of production). While this right has lost some of its previous importance for Canadian tax purposes, it is still important for the purpose of enabling a successor corporation, and a second successor corporation, to deduct exploration expenses of a predecessor, as set forth in paragraphs 8 and 9 of Section 66 of the Act. In addition, the right will be important to prospective purchasers subject to tax in the U.S.A., and should accordingly be specified in the concession in order to enhance its marketability.

(v) Sharing of production:

(A) Limitation of the rights of the state to purchase or take a percentage of production for use by or in the state.

(B) Delineation of the rights of the state to equity participation in the concession, and the percentage basis, cost of participation and terms of payment.

(vi) Voluntary disposition of the concession: Ensure the adequacy of rights to surrender or relinquish the concession, rights to assign without restriction to affiliates, or in the course of financing, and general rights to assign or otherwise dispose of the concession.

(vii) Involuntary dispositions: Consider the grounds for cancellation of the concession, provisions as to ownership of physical property in that event, and relief provided by arbitration and force majeure clauses to prevent arbitrary cancellation.

(viii) Monetary restrictions:

(A) Currency and exchange controls and restrictions.

(B) Restrictions on repatriation of income and capital.

Exemption from legislation otherwise applicable can sometimes be obtained, in which case the concessionaire must ensure that the exemption is properly granted, and is binding on all departments of the host government. 


\section{ASSESSING THE INVESTMENT CLIMATE}

While the attractiveness of the area in question from a geological point of view, the terms of the concession and applicable fiscal laws will be prime determinants in the decision whether or not to undertake operations in the area, the following matters should also be considered:

(a) Available guarantees against nationalization through intergovernmental treaties or otherwise, and available insurance.

(b) Degree of restriction on foreign ownership of enterprises in the host country.

(c) Level of political and economic stability.

(d) Historical attitude towards sanctity of contract and property rights.

(e) Special investment incentives, if any.

(f) Existence and terms of bilateral tax treaties with Canada.

(g) Flexibility and requirements of local company laws.

(h) Degree of government interference with the business community.

(i) Relations of the host country with neighbouring countries, as such will affect the ability to obtain supplies and market production.

(j) Availability of local or neighbouring markets, and problems in transporting any production to such markets.

(k) Availability of skilled and unskilled labour locally.

\section{CHOOSING A CORPORATE VEHICLE}

Prior to entering into a concession agreement, some internal corporate tax planning is required in order to ascertain the most advantageous manner in which the concession might be owned or held. Broadly stated, the choice is between the use of a branch of the company acquiring the concession (the "parent"), and an arrangement involving the use of one or more subsidiaries of the parent. The following alternative means of holding the concession are commonly considered:

(a) A branch of the parent.

(b) A subsidiary of the parent, incorporated and resident in Canada.

(c) A subsidiary, resident in Canada but incorporated outside of Canada.

(d) A subsidiary resident outside of Canada and incorporated outside of Canada.

(e) Use of a subsidiary, but entering into special arrangements for the purpose of effecting consolidation of accounts for Canadian tax purposes, in the same manner as if a branch of the parent had been used.

(f) Use of one or more subsidiaries resident, as appropriate, outside of Canada, for the purpose of using "tax havens" and tax treaties to reduce taxes.

Matters to be considered in assessing the alternatives will now be discussed under the headings General Considerations, and Canadian Income Tax Considerations.
A. General Considerations
(1) host country legislation 
The laws of the host country may require the incorporation of a company locally, or otherwise restrict those entities which may hold petroleum rights.

In cases where local incorporation is not mandatory by law, it may in fact be necessary, by virtue of tax incentives or other preferred treatment afforded to locally incorporated companies (and conversely, penalties, additional taxes, or other impediments imposed on branches of foreign corporations).

When considering the registration of a branch of the parent in the host country, the likelihood of the world income of the parent being taxed in the host country must be considered, together with the likelihood of changes which would have that result, such as a change in the residence of the parent or a change in the law of the host country.

(2) limitation of liability

A subsidiary is often used primarily for the purpose of attempting to limit the liability of the parent. The importance of this factor will depend on the risks to which the concessionaire is exposed, the extent to which adequate insurance can be obtained, and whether parental guarantees or performance bonds are required by the host country. If the concession is being acquired jointly with other participants who are using subsidiaries without other assets, the use of a subsidiary to avoid becoming the primary target for claims arising from operations should be considered. (3) flexibility in dealing with the concession

Consider whether restrictions on transfer of the concession can, in effect, be avoided by the transfer of shares in the capital stock of the concessionaire. If so, the use of a subsidiary may provide greater flexibility.

\section{B. Canadian Income Tax Considerations}

No "rule of thumb" can be formulated as to which corporate structure is the most advantageous, from a Canadian tax point of view, as each situation must be assessed independently, having regard to the laws of the host country, treaties with the host country, and the particular situation of the company in question. The Canadian income tax rules which should be kept in mind in making such assessments can, however, be stated, and some general conclusions can be drawn therefrom. The application of these rules to each of the six alternatives mentioned at the beginning of this section of the paper will now be considered. (References are to sections of the Income Tax Act of Canada, as of March 31, 1975. As mentioned at the beginning of this paper, the "parent" is assumed to be taxable as a resident of Canada.)

\section{(1) a branch of the parent}

(i) Acquisition Costs

If the concession is a foreign resource property within the meaning of Section 66(15)(f), the costs of acquisition will be considered as a foreign exploration and development expense [66(15)(e)(iii)], and will be deductible from world income to the extent of the greater of 10 percent of such costs or the amount of the taxpayer's foreign resource income, as provided in Section 66(4).

(ii) Exploration and Development Expenses 
Expenses coming within the definition of foreign exploration and development expenses, contained in Section 66(15)(e), are deductible as specified in Section 66(4), outlined above.

(iii) Interest Expense

Interest on loans, the proceeds of which are expended in exploration and development operations, will be deductible against world income, provided that the conditions of Section 20(1)(c) are met. An election to treat such expense as exploration and development expense is available in the circumstances described in Section 21(2).

(iv) Income from the Concession

The income resulting from successful exploration and development operations will be taxed as income at normal corporate rates, as set forth in Section 123. To the extent that it is income described in Section 66(4)(b), there may be deducted therefrom unclaimed foreign exploration and development expenses. Credits will be allowed against Canadian tax as set forth in Section 126, for taxes paid in the host country.

(v) Remittance of Income to Canada

There is no Canadian consequence of transfers from a foreign branch to a Canadian office of the "parent", although there may well be consequences in the host country.

(vi) Treatment of Proceeds of Disposition of the Concession

Arrangements in the nature of a "farmout", as discussed in International Bulletin IT-125, are not treated by the Department as being dispositions. Proceeds of dispositions within the meaning of Section 54 are taxable as set forth in Section 59. If the concession is a foreign resource property, the proceeds on the disposition thereof are a type of income against which foreign exploration and development expenses may be deducted. The concession may be disposed of without immediate tax consequences in the following situations, provided that the requirements of the relevant sections of the Act are complied with:

(A) Transfer by a shareholder under Section 85 to a Canadian corporation (defined in Section 89(1)(a) as being resident in Canada and either incorporated in Canada or resident in Canada from June 18, 1971 to the relevant time), which has not previously carried on business.

(B) Amalgamation of the company holding the concession, if it is a Canadian corporation, with another Canadian corporation, under Section 87.

(C) The concession may be disposed of, by virtue of Section 97(2), to a partnership, all of the members of which were, at the relevant time, resident in Canada.

A disposition cannot be made to a joint exploration corporation under Section 66(10) without tax consequences, as that section does not permit the renunciation of foreign exploration and development expenses to shareholders.

(vii) Conclusion 
The advantage of using a branch of the "parent" is the ability to consolidate income and expenses from different foreign operations for Canadian tax purposes. If the operation is to be subject to Canadian tax at all, the greatest flexibility and the most favourable Canadian tax treatment is probably achieved by the use of a branch of the "parent". These advantages may be offset, however, by the other considerations mentioned under the subheading General Considerations above.

(2) a branch of a wholly owned subsidiary of the parent incorporated and resident in Canada

(i) Treatment of Income and Expenses

Income and expenses will be treated, in the hands of the subsidiary, in the same manner as described above with respect to the "parent". However, the expenses incurred can only be set off against the income of that subsidiary. Similarly, expenses incurred by the "parent", in other operations not conducted through this subsidiary, cannot be used to offset income from this subsidiary's operations.

(ii) Remittance of Income

Income may be transferred, by way of dividend, to the "parent", without Canadian tax consequences. (Dividends are included in the "parent's" income by Section $82(1)(\mathrm{a})$, and then deducted by virtue of Section 112(1).)

(iii) Disposition of the Concession

The treatment will be the same as outlined above, with respect to the "parent". In addition, the concession may be transferred to the "parent", without tax consequences, by virtue of a "winding-up" under Section 88, if both the "parent" and the subsidiary are Canadian corporations. The "winding-up" itself can be effected without tax consequences only if the subsidiary has no designated surplus. If the "parent" is a Canadian corporation, unclaimed foreign exploration and development expenses may be passed to it by virtue of Section 66(8), if it acquires substantially all of the subsidiary's property used in carrying on its business outside of Canada.

(iv) Conclusion

Some flexibility is lost, from the Canadian tax planning point of view, to the extent that income and expenses from the operation in question cannot be consolidated with income and expenses from other foreign operations of the parent. Whether or not this is important will depend on the particular situation of the "parent". If it is subsequently decided that it would be better to have the "parent" hold the concession, it is theoretically possible to make the transfer by virtue of a "winding-up", under Section 88, without significant tax consequences in Canada (which may not be the case in the host country).

(3) a subsidiary resident in Canada

but incorporated outside of Canada

The Canadian treatment of income and expenses, in this situation. is 
the same as described above with respect to a subsidiary incorporated in Canada. It will not be possible to take advantage of the Section 88 "rollover" if it becomes necessary to transfer the concession to the "parent", as the subsidiary will not be a Canadian corporation if it was incorporated after June 18, 1971 [see Section 89(1)].

A non-tax consideration is the relative convenience of operating and making any necessary corporate re-organizations under the laws of a foreign country, as opposed to the laws of the Province of Alberta or of Canada.

While the subsidiary is a resident of Canada, income and expenses will be treated in roughly the same manner as if the company were incorporated in Canada. Some additional flexibility in planning is possible, by virtue of the subsidiary's being in a position to become a non-resident of Canada. This advantage may be reduced somewhat if the concession is a property which would be deemed to be disposed of under Section 48 in the event of the company becoming a non-resident.

(4) a subsidiary resident outside of Canada

and incorporated outside of Canada

As the subsidiary is not a resident of Canada, it will not be taxed on income earned outside of Canada.

Dividends to the parent company will, however, be taxable under Section 90, except to the extent that a deduction is permitted under Section 113. By way of generalization, it may be said that if tax is imposed in the host country on income from the concession at a rate which is not less than the rate which would have been imposed in Canada on the same income, dividends can be made to the parent, essentially without attracting Canadian tax.

The subsidiary will be a controlled foreign affiliate, within the meaning of Section 95(1)(a)(i), and the foreign accrual property income rules of Section 91(1) will, accordingly, apply to the "parent". However, there should be no practical consequence to the "parent". If the concession has been properly structured, income thereunder will constitute active business income, which may be accumulated outside of Canada without consequence to the "parent".

Proceeds of disposition of the concession will not be subject to tax in Canada, until remitted as a dividend.

It would appear that the subsidiary may be wound up without tax consequence to the "parent", as Sections 84(2) and 15(1) do not appear to apply. If the shares of the subsidiary are cancelled, they will be deemed to have been disposed of for proceeds equal to the fair market value of all funds and property received in consequence of the liquidation, giving rise to a capital gain or loss in the hands of the parent.

In the event that taxes in the host country are lower than in Canada, there will be possible advantages in using a subsidiary not resident in Canada, as discussed below under the headings "Use of Tax Treaties" and "Use of Tax Havens".

(5) use of a subsidiary, entering into special arrangements for the purpose of effecting consolidation of accounts for Canadian tax purposes, in the same manner as if a branch of the parent had been used

A number of arrangements are currently in use under which the "parent" becomes obliged to pay exploration and development expenses 
in connection with a concession, and in return receives all of the subsidiary's share of production under such concession. Such arrangements (often referred to as "flow-through" or "illustrative" agreements) are common in North Sea areas, where local laws require that the concession be held by a company incorporated in the host country. These arrangements are made in such a manner that there is no disposition of the concession for Canadian tax purposes or, that if there is, it is done at a time when the concession has only nominal value. It is essential to these schemes that the "parent" be treated, in the host country, as the entity which is taxed on production income. If the host country does not recognize the arrangement, and taxes the subsidiary, the subsidiary will become entitled to the tax credits which the "parent" requires in order to prevent double taxation in Canada. If this happens, the tax planner involved may wish to consider suicide!

This type of arrangement should achieve the same result as if the concession were held by a branch of the parent, as long as the transaction cannot be said to be artificial, and the inadequate consideration rules of Section 69 do not apply.

If the concession is acquired by the parent, and it is subsequently desired to register the concession in the name of a subsidiary, this can be done without resort to a disposition under Section 59 , so long as the agreement transferring title to the subsidiary disposes of no more than a bare legal interest. In this circumstance, an "illustrative" agreement is not necessary for Canadian purposes, although some supplementary agreement may be necessary for the purposes of the host country, to ensure that the "parent", rather than the subsidiary, is taxed on income from the concession.

A similar result can be obtained by the "parent's" agreement to finance the exploration and development expenses of the subsidiary in return for a royalty equal to the subsidiary's share of production from the concession. The "parent's" income will then be in the form of royalty, which may attract withholding tax in the host country. For Canadian purposes the "parent", rather than the subsidiary, will claim the exploration and development expenses, and may deduct the same from the royalty income received by it; that is to say that results are roughly the same as if the concession were held by the "parent". A possible drawback is that the expenses of the "parent" cannot be passed on to a successor, or second successor, corporation, under paragraphs 8 or 9 of Section 66, unless the "parent" also has the right to take petroleum from the wells in question.

As mentioned above, care must be taken to avoid the application of the rules relating to artificial transactions and inadequate consideration. If the subsidiary is deemed to have disposed of the royalty for less than its fair market value, the subsidiary will be deemed to have proceeds of disposition equal to the fair market value, while the "parent" will be deemed to have acquired the royalty at the lesser amount which it actually pays.

(6) use of one or more subsidiaries resident as appropriate outside of Canada, for the purpose of using tax havens and tax treaties to reduce taxes

Use of Tax Havens.

If the income taxes imposed in the host country are at least as great 
as the taxes which would be imposed in Canada, income from the concession received by a corporation resident in Canada will not attract additional tax in Canada, by virtue of the tax credit provisions of Section 126. In this situation, there is little incentive to make use of a "tax haven"; however, if the income from the concession is taxed at a lower level in the host country than it would be in Canada, additional tax will be payable in Canada. It is in this situation that there is value in using a subsidiary resident outside of Canada [which likely must be incorporated outside of Canada, by virtue of the deemed residence provisions of Section 250(4)]. As the income from the concession will be active business income, the foreign accrual property income rules of Section 91 will not apply. The income may accordingly be accumulated offshore without attracting Canadian tax until such time as it is remitted to Canada. This is also true if the subsidiary holding the concession is held by another subsidiary of the "parent", resident outside of Canada.

The success of this type of scheme is dependent on the residence of the subsidiary in question being maintained in the desired jurisdiction, which may pose practical problems, as the central management and control of the company must therefore be maintained outside of Canada.

Use of Tax Treaties.

Where withholding taxes on dividend or royalty payments from the host country to Canada are high, or where Canada taxes dividends from foreign affiliates because of the absence of a treaty with the host country, the impact of such taxes may be reduced, by the use of a foreign-controlled affiliate, resident in a third country which has favourable treaties with both Canada and the host country. The Netherlands and Netherlands Antilles are popular areas for this purpose, as they have a comprehensive network of treaties which often reduce withholding tax in the source country below the 15 percent level which is common in Canadian treaties.

\section{Conclusion}

Proper advice can be given to a prospective participant in a foreign operation only after examining the proposed operation in light of the relevant laws and international conventions of the host country and Canada, and in light of the operations and financial situation of the particular company in Question. The variety of circumstances which can be encountered in connection with a foreign operation is virtually without limit. This paper, accordingly, has not attempted an exhaustive study of, but is representative of, the types of questions which legal counsel can expect to be required to consider in connection with the acquisition of exploration and production rights outside of Canada. 